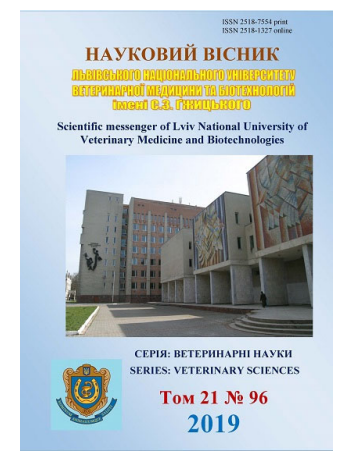

\author{
Науковий вісник Львівського національного університету \\ ветеринарної медицини та біотехнологій імені С.3. Гжицького. \\ Серія: Ветеринарні науки
}

Scientific Messenger of Lviv National University of Veterinary Medicine and Biotechnologies. Series: Veterinary sciences

\title{
D-vitamin status of cattle depending on the conditions of detention and physiological state
}

\author{
L.L. Yuskiv ${ }^{1}$, V.V. Vlizlo ${ }^{1,2}$, N.R. Mot'ko ${ }^{1}$ \\ ${ }^{1}$ Stepan Gzhytskyi National University of Veterinary Medicine and Biotechnologies Lviv, Ukraine \\ ${ }^{2}$ State Scientific Research Control Institute of Veterinary Medicinal Products and Feed Additives, Lviv, Ukraine
}

Article info

Received 14.10.2019

Received in revised form 15.11.2019

Accepted 18.11.2019

Stepan Gzhytskyi National University of Veterinary Medicine and Biotechnologies Lviv, Pekarska Str., 50, Lviv, 79010, Ukraine.

Tel.: +38-097-552-07-26 E-mail:yuskiv_ll@ukr.net

State Scientific Research Control Institute of Veterinary Medicinal Products and Feed Additives, Donetska Str. 11, Lviv, 79019, Ukraine
Yuskiv, L.L., Vlizlo, V.V., \& Mot'ko, N.R. (2019). D-vitamin status of cattle depending on the conditions of detention and physiological state. Scientific Messenger of Lviv National University of Veterinary Medicine and Biotechnologies. Series: Veterinary sciences, 21(96), 124-128. doi: $10.32718 /$ nvlvet 9622

The article contains data on the content of the active metabolite of vitamin D3-25-OHD, the concentration of calcium, phosphorus, magnesium and the activity of alkaline phosphatase in the blood of lactating cows in different periods of keeping. The experiment was performed by the method of periods on the cowsanalogues for the 4th month of lactation. Cows are divided into three groups of five heads, each depending on the sampling period: winter stall (January), summer pasture (July) and autumn stall (October) for one year. The blood for tests was collected from the jugular vein before morning feeding in winter-stall, summer-pasture, and autumn-stall hold periods. The composition and nutrition of the diets of cows were also analyzed. Changes in the content of $25-\mathrm{OHD}_{3}$ in the blood of cows were determined depending on the season and conditions of keeping. The lowest level of 25-OHD was in the winter-stall holding period and was $22.38 \pm 3.58 \mathrm{nmol} / \mathrm{l}$ and the highest was in the summer pasture. In the autumn-stall period, the level of 25 $\mathrm{OHD}_{3}$ decreased relative to the summer pasture, but was higher than in the winter-stall $(P<0.05)$. The total calcium content of the serum of cows was highest in the summer pasture and winter-stallion periods and was, respectively, 2.96 and $2.90 \mathrm{mmol} / \mathrm{l}$. In the autumn-stalling period, the total calcium content decreased and was significantly lower compared to the summer pasture period $(P<0.05)$. Changes in the total calcium content of cows' blood during different retention periods were due to changes in its fractions. The activity of total alkaline phosphatase and its bone isoenzyme in the blood of cows at 4 months of lactation varied in contrast to the content of $25-\mathrm{OHD}_{3}$.

Key words: cows, vitamin D3, metabolism, blood, 25-hydroxycholecalciferol.

\section{Забезпеченість вітаміном D та показники мінерального обміну лактуючих корів залежно від сезону та умов утримання}

\author{
Л.Л. Юськів ${ }^{1}$, В.В. Влізло ${ }^{1,2}$, Н.Р. Мотько ${ }^{1}$ \\ ${ }^{1}$ Львівський національний університет ветеринарної медицини та біотехнологій імені С.3. Гжсицького, м. Львів, \\ Україна \\ ${ }^{2}$ Державний науково-дослідний контрольний інститут ветеринарних препаратів та кормових добавок, \\ м. Львів, Украӥна
}

У статті наведено дані щзодо вмісту активного метаболіту вітаміну $D_{3}$ - 25-ОНD, концентрації кальцію, фосфору, магнію та активності лужної фосфатази в крові лактуючих корів у різні періоди утримання. Дослід проведено методом періодів на коровах-аналогах на 4-му місячі лактації. Корів поділено на три групи по п'ять голів у кожній залежно від періоду відбору проб: зимово-стійловий (січень), літньо-пасовищний (липень) та осінньо-стійловий (жсвтень) упродовж одного року. Для біохімічних досліджень від корів брали кров з яремної вени у зимово-стійловий, літньо-пасовищний $і$ осінньо-стійловий періоди утримання. 
Також проводили аналіз складу і поживності раџіонів корів. Встановлено зміни вмісту 25-ОНDз у крові корів залежно від сезону та умов утримання. Найнижчий рівень 25-ОНD, був у зимово-стійловий період утримання $і$ становив 22,38 $\pm 3,58$ нмоль/л, а найвищий - у літньо-пасовищний. В осінньо-стійловий період рівень 25-OHD знизився щзодо літньо-пасовищного, проте був вищии, ніж у зимово-стійловий $(P<0,05)$. Вміст кальцію загального у сироватці крові корів був найбільщим у літньо-пасовищний $і$ в зимово-стійловий період утримання і становив, відповідно, 2,96 i 2,90 ммоль/л. В осінньо-стійловий період вміст кальцію загального знизився та був вірогідно нижчим у порівнянні з літньо-пасовищним періодом $(P<0,05)$. 3міни вмісту кальцію загального у крові корів у різні періоди утримання відбувались за рахунок змін його фракцій. Активність загальної ЛФ $і$ ї̈ кісткового ізоензиму в крові корів на 4-му місяці лактації змінювалася протилежно до вмісту 25-OHDз.

Ключові слова: корови, вітамін $D_{3}$, метаболізм, кров, 25-гідроксихолекальцииферол.

\section{Вступ}

В організмі корів у період лактації підвищується інтенсивність мінерального обміну, а тому велике значення має ступінь забезпеченості жиророзчинними вітамінами, зокрема вітаміном D. Це обумовлено стимулювальним впливом його активних метаболітів на різні ланки обміну речовин та процеси проліферації у молочній залозі (Horst et al., 1994; Vlizlo, 2015). $1,25(\mathrm{OH})_{2} \mathrm{D}_{3}$ через вплив на рецептори у молочній залозі стимулює транспорт Са у молочну залозу (Fry et al., 1980; Horst et al., 1997). Дослідженнями встановлено, що вміст вітаміну D і його метаболітів у молоці залежить від D-вітамінного статусу корів (McDermott et al., 1985; Guneser \& Karagul Yuceer, 2012). Тому зі збільшенням продукції молока, зростають також витрати цього вітаміну.

Забезпечення організму великої рогатої худоби вітаміном D відбувається двома шляхами - екзогенним (iз кормів рослинного і тваринного походження) та ендогенного (синтезу холекальциферолу в шкірі під впливом ультрафіолетового опромінення). Ці два шляхи доповнюють і замінюють один одного (Horst et al., 1994; Vlizlo, 2015).

Маловивченим є питання, як довго рівень вітаміну D, утворений ендогенним шляхом, може зберігатися в організмі і підтримувати його фізіологічний Dвітамінний статус. Виходячи зі сказаного, науковопрактичний інтерес становить вивчення ступеня забезпеченості вітаміном D лактуючих корів у різні періоди утримання та залежно від рівня продуктивності.

Метою роботи було з'ясувати біохімічні процеси впливу сезонних i годівельних факторів на Dвітамінний статус і показники мінерального обміну в крові лактуючих корів української чорно-рябої молочної породи.

Для досягнення мети необхідно було розв'язати наступні завдання: визначити вміст активного метаболіту вітаміну $\mathrm{D}_{3}-25-\mathrm{OHD}_{3}$, концентрацію кальцію, фосфору, магнію та активність лужної фосфатази в крові лактуючих корів у зимово-стійловий, літньопасовищний i осінньо-стійловий періоди, а також провести аналіз складу та поживності кормів.

\section{Матеріал і методи досліджень}

Дослід проведено методом періодів на коровах української чорно-рябої молочної породи на 4-му місяці лактації, аналогів за віком, живою масою та молочною продуктивністю (добовий надій в середньому становив 18 кг молока). Корови були поділені на 3 групи по п'ять голів у кожній, залежно від періоду відбору проб: зимово-стійловий, літньо-пасовищний та осінньо-стійловий упродовж одного року. У стійловий період утримання корови отримували раціон із кормів даного господарства, збалансований за основними поживними речовинами. У літньопасовищний період корів випасали на природних пасовищах i додатково згодовували комбікорм i зелену масу. Забезпеченість раціонів у різні періоди утримання за загальною поживністю становила 80100\%. У кожному періоді використовували коріваналогів на 4-му місяці лактації.

Проби крові відбирали одноразово у такі періоди утримання: зимово-стійловий, літньо-пасовищний та осінньо-стійловий.

У крові визначали вміст 25-OHD 3 імуноензимним методом ELISA, відповідно до протоколу для використання набору 25-Hydroxy Vitamin D "Immundiagnostik" (Kondrahin, 2004; Vlizlo, 2012). Вміст кальцію (загального, протеїнзв'язаного і ультрафільтрувального), фосфору неорганічного, магнію та активність лужної фосфатази (ЛФ) у сироватці крові визначали, використовуючи біотест-набори фірми "Pliva Lachema" (Чехія) (Vlizlo, 2012). Активність ізоензимів лужної фосфатази вивчали з використанням інгібіторів і розраховували згідно з методом, описаним в роботі (Vagner et al., 1981; Levchenko, 2010). Статистичну обробку експериментальних даних проводили загальноприйнятими методами варіаційної статистики з вирахуванням середнього значення (M) й похибки ( $\pm \mathrm{m})$. Задля визначення достовірності відмінностей між одержаними величинами двох вибірок використовували t-критерій Стюдента. Результати вважали вірогідними при $\mathrm{P}<0,05-0,001$. Опрацювання і статистичну обробку одержаних цифрових даних виконували за допомогою програми Microsoft Excel.

\section{Результати та їх обговорення}

Для з'ясування особливостей забезпечення організму корів вітаміном D у різні періоди утримання ми провели аналіз поживності згодовуваних кормів раціонів разом із показниками крові, які характеризують D-вітамінний статус організму (вміст 25-OHD 3 і показники мінерального обміну).

У зимово-стійловий період коровам згодовували раціон, у складі якого містилися 4 кг сіна лучного, 20 кг силосу кукурудзяного, 10 кг сінажу різнотрав- 
ного, 4 кг дерті пшеннично-вівсяної у співвідношенні $3: 1,0,5$ кг шроту соєвого і 1,5 кг меляси.

У період від травня по жовтень корів випасали на природніх пасовищах і додатково згодовували кормосуміш. Раціон годівлі дійних корів у літньопасовищний період складався із трави злаковобобової, дерті пшеничної, дерті ячмінної, меляси, солі кормової. За такого складу раціону забезпечувалась потреба корів із добовим надоєм 18 кг молока в основних елементах живлення (табл.). Зокрема, забезпеченість корів в обмінній енергії із раціону становила 163,41 МДж і була вищою від норми на 2,77\%. У цьому раціоні відзначено меншу кількість (щодо нор- ми) сухої речовини на 1045,00 г (6,33\%), сирого протеїну - 16,10 г $(0,75 \%)$, перетравного протеїну 28,00 г (1,95\%), сирого жиру - 15,00 г (3,09\%), сирої клітковини - 70,50 г $(1,7 \%)$, крохмалю - 122,50 г $(5,76 \%)$ і цукру $-54,20$ г (4,33\%).

У згодовуваному раціоні для дійних корів відзначено дефіцит жиророзчинних вітамінів та макро- $\mathrm{i}$ мікроелементів. Зокрема, нестача у вітаміні D становить 8000,0 MO на голову на добу, що в перерахунку на відсотки складає 58,82\%. Дефіцит вітаміну А відносно потреби складає 30000,0 МО, або 60\%. При цьому відзначено надлишок каротину на 195,65\% i вітаміну Е - 274,94\%.

\section{Таблиця}

Поживна цінність раціону годівлі дійних корів (добовий надій 18 кг ) у літньо-пасовищний період

\begin{tabular}{lcccc}
\hline \multicolumn{1}{c}{ Показники } & Норма & У раціоні & Відхилення, абсол. од. & Відхилення, \% \\
\hline ОЕ, ВРХ, МДж & 159,00 & 163,41 & 4,41 & 2,77 \\
Суха речовина, г & 16500,00 & 15455,00 & $-1045,00$ & $-6,33$ \\
Сирий протеїн, г & 2141,00 & 2124,90 & $-16,10$ & $-0,75$ \\
Перетр. протеїн, г & 1435,00 & 1407,00 & $-28,00$ & $-1,95$ \\
Сирий жир, г & 485,00 & 470,00 & $-15,00$ & $-3,09$ \\
Сира клітковина,г & 4130,00 & 4059,50 & $-70,50$ & $-1,70$ \\
Крохмаль, г & 2125,00 & 2002,50 & $-122,50$ & $-5,76$ \\
Цукор, г & 1250,00 & 1195,80 & $-54,20$ & $-4,33$ \\
Кальцій, г & 97,00 & 87,80 & $-9,20$ & $-17,80$ \\
Фосфор, г & 69,00 & 56,72 & $-12,28$ & 36,76 \\
Магній, Г & 26,00 & 35,56 & 9,56 & $-32,60$ \\
Сульфур, г & 33,00 & 22,24 & $-10,76$ & 278,88 \\
Ферум, мг & 1090,00 & 4129,80 & 3039,80 & $-41,65$ \\
Купрум, мг & 130,00 & $-54,14$ & $-2,70$ \\
Цинк, мг & 850,00 & 872,96 & $-22,98$ & 156,13 \\
Манган, мг & 850,00 & 2177,16 & 1327,16 & 8,53 \\
Кобальт, мг & 9,50 & 0,81 & $-58,70$ \\
Йод, мг & 11,50 & 10,31 & $-6,75$ & 195,65 \\
Каротин, мг & 610,00 & 1193,50 & $-60,0$ \\
Вітамін А, МО & 50000,0 & 20000,0 & $-58,82$ \\
Вітамін Д, МО & 13600,00 & 5600,00 & $-30000,0$ & 274,94 \\
Вітамін Е, мг & 545,00 & 2043,45 & $-8000,00$ & 1498,45 \\
\hline
\end{tabular}

Стосовно забезпечення тварин макроелементами, то слід відзначити нестачу кальцію у згодовуваному раціоні відносно потреби на 9,20 г, що в перерахунку на відсотки складає 9,48 \%, фосфору - 12,28 г (17,8\%). Співвідношення між кальцієм і фосфором становить $1,55: 1$. Дефіцит сульфуру відносно потреби становить 10,76 г, або $32,60 \%$. Поряд із цим, у раціонах дійних корів виявлено надлишок щодо норми за такими макроелементами: магній - 9,56 г (36,76\%) та калій - 56,64 г (54,99\%).

Аналізуючи поживність раціонів за мікроелементами, ми встановили нестачу купруму порівняно 3 потребою на 41,65\%, цинку - 2,70\% і йоду - 58,70\%. На противагу цьому, вміст мангану і кобальту був вищим за потребу на 156,13 і 8,53\%, відповідно.

При дослідженні крові дійних корів, які були поділені на 3 групи залежно від періоду відбору проб: зимово-стійловий (січень), літньо-пасовищний (липень) та осінньо-стійловий (жовтень) та за вказаних умов годівлі, нами встановлені сезонні коливання вмісту активного метаболіту вітаміну $\mathrm{D}_{3}-25-\mathrm{OHD}_{3}$ та показників мінерального обміну впродовж одного року (рис.). Зокрема, рівень 25-OHD 3 був найнижчим у зимово-стійловий період утримання і становив всередньому 22,38 нмоль/л. Найвищий рівень 25гідроксивітаміну $\mathrm{D}_{3}$ у крові корів був у літньопасовищний період, а порівняно із зимово-стійловим і осінньо-стійловим був вищим у 3,82 (Р < 0,001) і в 2,21 раза $(\mathrm{P}<0,001)$, відповідно. В осінньо-стійловий період вміст 25-гідроксивітаміну D знизився, проте відносно зимово-стійлового був вищим у 1,73 раза $(\mathrm{P}<0,05)$. При цьому забезпеченість раціонів дійних корів вітаміном D у зимово-стійловий період утримання становила 54\% від норми, а у літньопасовищний $-41 \%$ (див.табл.). 
25-ОН D (нмоль/л); ЛФ (Од/л)

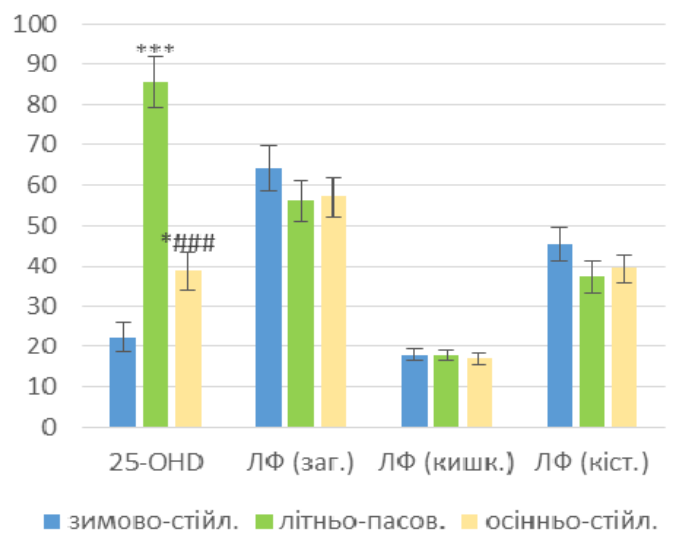

ммоль/л

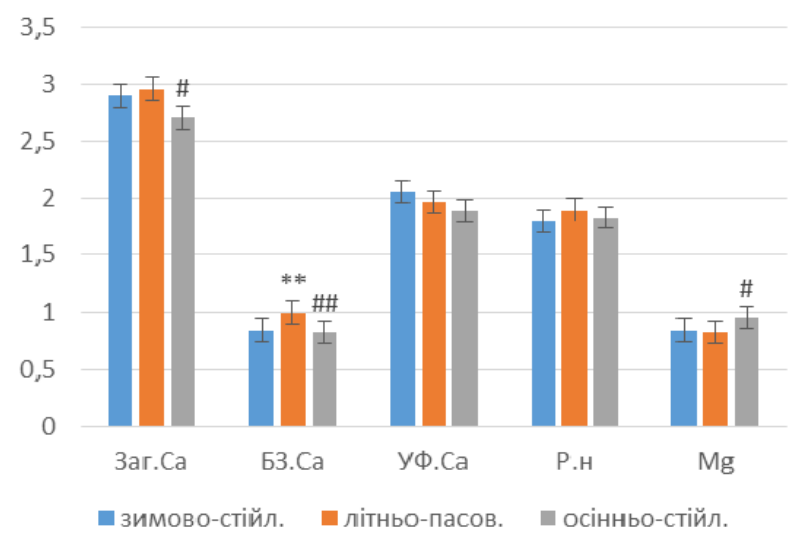

Рис. 1. Вміст $25-\mathrm{OHD}_{3}$ і показники мінерального обміну в сироватці крові корів у різні періоди утримання $(\mathrm{M} \pm \mathrm{m}, \mathrm{n}=5)$

Примітка: статистично вірогідні різниці стосовно 1) зимово-стійлового періоду утримання * $-\mathrm{P}<0,05$; ** $-\mathrm{P}<0,01$; *** $\mathrm{P}<0,001 ; 2)$ літньо-пасовищного періоду утримання \#-P $<0,05$; \#\#- $\mathrm{P}<0,01$; \#\# - $\mathrm{P}<0,001$

Отримані дані дають підставу вважати, що забезпечення організму корів вітаміном D відбувається i екзогенним, і ендогенним шляхом у різні періоди утримання, а також виявляють переваги метаболізму і прояву функціональної активності холекальциферолу, утвореного шляхом фотобіогенезу у літньопасовищний період.

Разом із різницями у показниках 25гідроксивітаміну $\mathrm{D}_{3}$ були виявлені зміни показників мінерального обміну в організмі корів у різні періоди утримання (рис. 1). Зокрема, вміст кальцію загального у сироватці крові корів був найбільшим у літньопасовищний і в зимово-стійловий період утримання $\mathrm{i}$ становив, відповідно, 2,96 і 2,90 ммоль/л. В осінньостійловий період вміст кальцію загального знизився та був вірогідно нижчим у порівнянні 3 літньопасовищним періодом $(\mathrm{P}<0,05)$. Зміни вмісту кальцію загального у крові корів у різні періоди утримання відбувались за рахунок змін його фракцій. Вміст кальцію білок-зв'язаного у літній період був вищим в 1,18 раза, порівняно 3 зимовим $(\mathrm{P}<0,01)$ та в 1,21 раза, порівняно осіннім періодом $(\mathrm{P}<0,01)$.

Вміст неорганічного фосфору в крові корів був найвищим у літній і осінній періоди, проте різниці були невірогідними. Також нами встановлені різниці у вмісті магнію у сироватці крові корів у різні пори року. Найнижчим він був у літньо-пасовищний період, а найвищим - в осінньо-стійловий.

При цьому у згодовуваному раціоні дійних корів відзначали незначні відхилення від потреби в кальції і фосфорі у стійловий і пасовищний періоди. Зокрема, у зимово-стйловий період відзначали надлишок кальцію (4\%) та дефіцит фосфору (15\%). У літньопасовищний період раціон дійних корів був дефіцитним за фосфором (18\%) і кальцієм (9\%), а їхне співвідношення було в межах норми і становило 1,55 (див. табл.). Отримані дані свідчать про значення рівня вітаміну D в організмі корів у засовоєнні і регуляції метаболізму кальцію і фосфору у період лактації.
Активність лужної фосфатази загальної і її кісткового ізоензиму у сироватці крові корів на 4-му місяці лактації змінювались протилежно до вмісту $25 \mathrm{OHD}_{3}$. Зокрема, у літньо-пасовищний період при найвищому рівні 25-гідроксихолекальциферолу активність лужної фосфатази була найнижчою, порівняно до інших періодів утримання.

Активність лужної фосфатази була найвищою у зимово-стійловий період утримання $\mathrm{i}$ становила $64,31 \pm 5,46$ Од/л. При цьому також відзначали найвищу активність кісткового ізоферменту. Активність кишкового ізоферменту лужної фосфатази у кількісному відношенні у крові корів у всі періоди досліджень суттєво не відрізнялась між собою. Однак у процентному відношенні активність кишкового ізоензиму була найвищою у літньо-пасовищний період $\mathrm{i}$ становила $32 \%$ відносно активності ЛФ загальної. У зимово-стійловий і осінньо-стійловий періоди утримання активність кишкового ізоензиму становила $29 \mathrm{i}$ 30\%, відповідно, від активності ЛФ загальної.

Отже, отримана нами динаміка змін вмісту 25гідроксивітаміну $\mathrm{D}_{3}$ у крові корів у різні періоди утримання свідчить про виражений вплив УФ-променів у літньо-пасовищний період утримання на забезпечення молочних корів вітаміном D ендогенним шляхом. Це підтверджується тим, що вміст активного метаболіту вітаміну $\mathrm{D}_{3}-25-\mathrm{OHD}_{3}$ у крові корів на $4-\mathrm{y}$ місяці лактації був найвищим у літньо-пасовищний період, а найнижчим - у зимово-стійловий період. Зниження D-вітамінного статусу корів у зимові місяці вказує на те, що корови здатні депонувати цей вітамін певний час та про засвоєння його із корму при низькому рівні $25-\mathrm{OHD}_{3}$ в крові. Динаміка змін вмісту кальцію загального, протеїн-зв'язаного і ультрафільтрувального, фосфору неорганічного, магнію, активності лужної фосфатази та іï ізоензимів на тлі змін концентрації 25-гідроксивітаміну $\mathrm{D}_{3}$ у крові корів у різні періоди утримання дає підстави вважати про вплив умов утримання, годівлі і рівня вітаміну $\mathrm{D}_{3}$ на мінеральний обмін. 


\section{Висновки}

Найнижчий рівень 25-ОНD 3 у крові корів був у зимово-стійловий період утримання і становив $22,38 \pm$ 3,58 нмоль/л, а найвищий - у літньо-пасовищний. В осінньо-стійловий період рівень 25-- $\mathrm{OD}_{3}$ знизився щодо літньо-пасовищного, проте був вищим, ніж у зимово-стійловий $(\mathrm{P}<0,05)$.

Динаміка вмісту 25-гідроксивітаміну $\mathrm{D}_{3}$ у крові корів у різні сезони року свідчить про вплив УФ променів у пасовищний періоду утримання на забезпечення молочних корів природньо-географічної зони Передкарпаття вітаміном D ендогенним шляхом.

Зміни вмісту кальцію загального і його фракцій, неорганічного фосфору, магнію та активності лужної фосфатази та іiі ізоферментів на тлі динаміки вмісту 25-гідроксивітаміну $\mathrm{D}_{3}$ в крові корів у різні періоди утримання дають підстави стверджувати, що сезонні фактори, умови утримання і годівлі та рівень вітаміну $\mathrm{D}$ впливають на мінеральний обмін.

\section{References}

Fry, J.M., Curnow, D.H., Gutteridge, D.H., \& Retallack, R.W. (1980). Vitamin D in lactation I. The localization, specific binding and biological effect of 1,25dihydroxyvitamin $\mathrm{D}_{3}$ in mammary tissue of lactating rats. Life Sci., 27, 1255-1263. doi: 10.1016/00243205(80)90218-0.

Guneser, O., \& Karagul Yuceer, Y. (2012). Effect of ultraviolet light on water- and fat-soluble vitamins in cow and goat milk. J. Dairy Sci., 95(11), 6230-6241. doi: $10.3168 /$ jds.2011-5300.
Horst, R.L., Goff, J.P., \& Reinhardt, T.A. (1994). Calcium and vitamin D metabolism in the dairy cow. J. Dairy Sci., 77(7), 1936-1951. https://www.ncbi.nlm.nih.gov/pubmed/7929956.

Horst, R.L., Goff, J.P., \& Reinhardt, T.A. (1997). Calcium and vitamin D metabolism during lactation. J. Mammary Gland Biol. Neoplasia., 2(3), 253-263. doi: 10.1023/a:1026384421273.

Kondrahin, I.P. (2004). Metody veterinarnoj klinicheskoj laboratornoj diagnostiki: spravochnik. M.: KolosS (in Russian).

Levchenko, V.I. (2010). Metody laboratornoi klinichnoi diahnostyky khvorob tvaryn. K.: Ahrarna osvita (in Ukrainian).

McDermott, C.M., Beitz, D.C., Littledike, E.T., \& Horst, R.L. (1985). Effects of dietary vitamin $\mathrm{D}_{3}$ on concentrations of vitamin D and its metabolites in blood plasma and milk of dairy cows. J. Dairy Sci., 68, 1959-1967. doi: 10.3168/jds.S0022-0302(85)81057-2.

Vagner, V.K., Putilin, V.M., \& Harabuga, G.G. (1981). Metody i rezul'taty issledovanija izofermentov (kishechnoj i pechenochnoj frakcij) syvorotochnoj shhelochnoj fosfatazy pri ostryh hirurgicheskih zabolevanijah organov brjushnoj polosti. Vopr. med. Himii, 27(6), 752-754 (in Russian).

Vlizlo, V.V. (2012). Laboratorni metody doslidzhen u biolohii, tvarynnytstvi ta veterynarnii medytsyni : dovidnyk. Lviv: Spolom (in Ukrainian).

Vlizlo, V.V. (2015). Zhyrorozchynni vitaminy u veterynarnii medytsyni ta tvarynnytstvi: monohrafiia. Lviv: Spolom (in Ukrainian). 